\title{
高抵抗材料の放電加工におけるジュール発熱を考慮した 工作物温度の非定常解析*
}

\author{
佐伯雄文 ${ }^{* *}$ 国枝正典 ${ }^{* * *} \quad$ 植木正憲 $^{\dagger} \quad$ 佐藤 裕 $^{\dagger}$
}

Transient Workpiece Temperature Analysis in the EDM Processes of High Electric Resistance Materials Considering Joule Heating

Takefumi SAEkI. Masanori KuNIEDA, Masanori Ueki and Yutaka SATOH

\begin{abstract}
This paper investigates the removal mechanism of high electric resistance materials in EDM processing by calculation of the distribution of the workpicce temperature taking the Joule heating caused by voltage drop in the workpiece into account. The voltage drop in the workpiece is extensive in the EDM processing of high electric resistance materials such as conductive ceramics. The voltage drop was therefore estimated by a numerical calculation, and its results were used to calculate the distribution of Joule heating inside the workpiece. Then considering both the Joule heating and the heat flux from the arc column, the time dependent workpiece temperature was computed by the finite-difference method. The expansion of arc column with time lapse which affects greatly the result of the above calculation was obtained experimentally and taken into account in the calculation. The calculated results show that the voltage drop mostly occurs in the vicinity of the discharge spot, and the calculated total voltage drop coincides well with the measured one. From the computed temperature distribution it is found that the Joule heating causes a temperature rise nearby the discharge spot which is comparable to what is given by the heat flux from the arc column, which was confirmed by the measured material removal by a single pulse which is greater than the removal of steel. Consequently, sufficient cooling of the discharge spot may assure the stability of machining and increase the material removal rate of conductive ceramics rather than metallic materials
\end{abstract}

Key words: EDM. high electric resistance material, ceramics, specific resistance, voltage drop in workpiece, Joule heating

\section{1. 緒言}

セラミックスやシリコンウエハなどは，高硬度，低じん性であ るため, 一般に切削などに代表される機械加工が困難な材料であ る. そこで，絶縁性材料に故意に導電性物質を混入し嫃結した材 料, あるいはそれ自体に比較的導電性のある材料などについて放 電加厂の試みが多くなされている1)〜8). しかし，加工が不安定で 異常放電を起こしやすいため，パルスの休止時間を十分長くとる 必要がある ${ }^{112)}$ ．また，加 $匚$ くずは金属を加工したた場合の溶融再凝 固型の球形の加工くずとは限らず，ぜい性破俵により剥離した無 定形の加工くずが存在する ${ }^{3)}$ 4) 等, 特有の加 工見象の存在をうかが わせる報告がなされている.

道電性のあるセラミックスなどの電気抵抗の大きな材料を放電 加工する場合，放電中に工作物内部で材料の大きな比抵抗に起因 する電压降下が生じることが指摘されている 工作物内部の3次元的な電位分布を测定することは困難である。 そ こで, 本研究では, 放電中の I作物内部での電压降下を数值解析 により求める，さらに，この電た降下が加工晛象に与える影炇と して, Rich ${ }^{9)}$, 鳳 ${ }^{10)}$ が指摘するように放電点でのジュール発熱を 考虑する，すなわち，ジュール発熱の除去機構への影響を調べる ために，熱源としてアーク柱からの熱流入に加えて，「.作物内部 のジュール発熱を考虑に入れた一つの放電パルス中の工.作物温度 の非定常解析を行う。そして, ジュール発熱の工作物除去作用へ の奇与を明確にし，高抵抗材料の放電加工に特有な加工晛象を明 らかにすることを目的とする.

$\mathrm{Rich}^{9)}$ は定常アークについて, 電極内の電位分布の解析解を求

* 原稿受付 平成 7 年 6 月 29 日

** 学生会員 東京農工大学大学院 (東京都小金井甫中町 2-24-16)

*** 正会員 東京農工大学工学部

† 新日本製鉄(株) 先端技術研究所（川崎市中原区.井田 1618）
め, それを用いて陰極点近傍のジュール発熱分布の定常解を求め た. さらに, 陰極点近傍にジュール発熱による半球状の均一な等 源が存在すると仮定してジュール発熱のみによる電極温度上昇を 近似的に求めた。 そして, 比抵抗が比較的大きな $\mathrm{Hg}, \mathrm{Fe}, \mathrm{Bi}$ 等の金 属材料ではジュール発熱による温度上昇がアーク柱からのイオン 衙揧により流入する熱による温度上昇に匹敵すると指摘している.

しかし，Rich自身が指摘しているように，ジュール発熱につい ての解析結果は, 根拠なく仮定されたアーク柱值径に大きく左右 される.さらに, アーク柱からの熱流束については, 実際の電極 の溶融域と解析による溶融域を比較して求めているが, この熱流 束の計算結果もアーク柱直径に大きく依存するため, アーク柱か らの熱流束を正しく求めているとは言えない.

そこで本研究では, まず電極材料が炭素銅でも高抵抗材料でも アーク柱での電圧降下やアーク柱值径が同じという近似のドでは あるが, 高抵抗材料の電压降下の解析結果を坚测した電圧降トと 比較することによって, 膨張するアーク柱直径の時間変化を求め た．また，アーク柱からの熱の流入については実測に基づく值を 用いた，そして，アーク柱の膨張により刻々変化するジュール発 熱とアーク柱からの熱流束の両方を考虑した工作物温度の非定常 解析を行った。

\section{2. ジュール発熱を考虑した熱伝導解析の方法}

\section{1 解析全体のアルゴリズム}

本研究で行ったジュール発熱を考虑に入れた非定常熟伝導解析 の手順を図にに示す。はじめに，工作物内部の電位分布解析を行う. そして, この結果から工作物内の電流密度分布を求め, さらに ジュール発熱分布を計算する. 次に熱源としてアーク柱からの熱 流束に加えて, 先に計算した工作物内のジュール発熱も考虑に入 れて，工作物の温度分布解析を行う。これらの計算をアーク柱直 徍の時間変化を考虑に入れて計算する. 


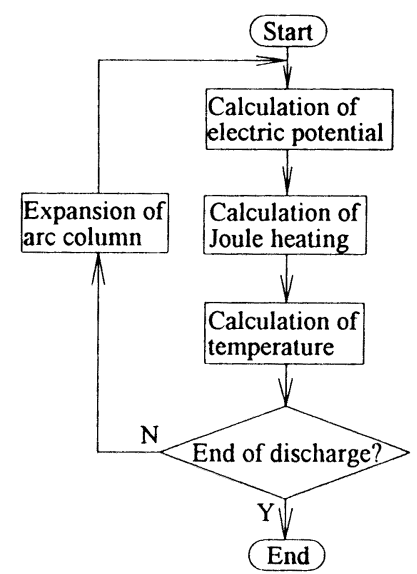

Fig.1 Flowchart

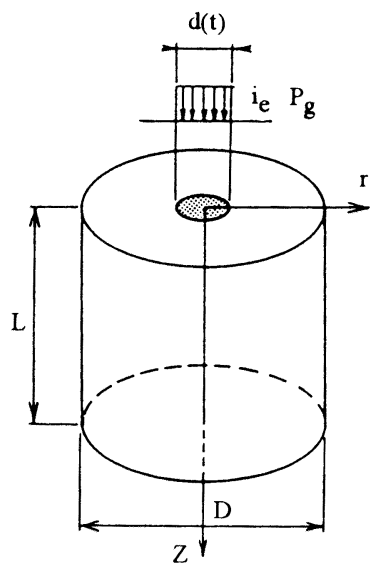

Fig. 2 Model of workpiece
本研究では, 図2に示すような時間とともに直徉 $\mathrm{d}(\mathrm{t})$ の変化する 円板状の放電点を上面中心に持つ, 直径D, 長さLの円筒形の工作 物モデルを用いた。 このモデルにおいて, 円周方向については電 荷及び熱の流れがないと考えることができる．したがって，図 $3 に$ 示すように，工作物の中心軸を頂点とする頂角 $\Phi$ の扇型を底面と する柱状の立体について半径方向に長さ $\Delta \mathrm{r}$, 軸方向に高さ $\Delta Z$ の メッシュに分割し，軸対称2次元問題として差分法による解析を 行った。 なお，比抵抗や熱伝導率，比熱などの物性值については, 簡単のため温度依存性は考虑せず, 室温の值で一定として扱った。 また，工作物の除去については考虑に入れなかった．

以下に図1のフローチャートの順に各ステップの説明を行う.

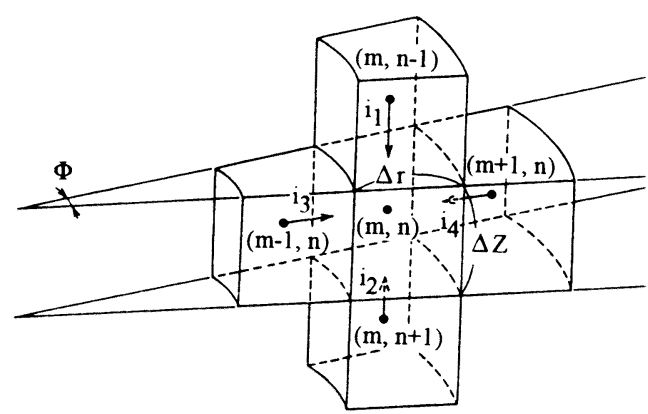

Fig.3 Continuity of electric current in a control-volume

\section{2 電位分布解析}

図3に示す工作物内のある一つのメッシュ (m, n) において, 上下 及び内外に隣接するメッシュから流入する電流の代数和は電荷保 存則より0となるので, メッシュ $(\mathrm{m}, \mathrm{n})$ の電位 $\mathrm{v}_{\mathrm{m}, \mathrm{n}}$ に関する方程式 が以下のように導出できる.

$$
\frac{S_{1}\left(v_{m, n-1}-v_{m, n}\right)}{\rho \mathcal{} Z}+\frac{S_{2}\left(v_{m, n+1}-v_{m, n}\right)}{\rho \mathbb{L}}+\frac{S_{3}\left(v_{m-1, n}-v_{m, n}\right)}{\rho \Delta r}+\frac{S_{4}\left(v_{m+1, n}-v_{m, n}\right)}{\rho \Delta}=0
$$

ここで, $\mathrm{S}_{1} \sim \mathrm{S}_{4}$ は各々 $\mathrm{i}_{1} \sim \mathrm{i}_{4}$ の電流が流入する面積, $\rho$ は工作物 の比抵抗， $\Delta Z, \Delta \mathrm{r}$ はそれぞれ軸方向及び半径方向に隣接する メッシュの中心間の距離, vはメッシュの電位である.

なお、電位分布解析における境界条件は以下のように設定した. 放電点において放電電流はアーク柱から工作物へ一様な分布を 持って流入すると仮定した. したがって, アーク柱からの放電電 流が流入するメッシュにおいては, 放電電流 $\mathrm{i}$ eをアーク柱の断面 積 $(\pi / 4) \times(\mathrm{d}(\mathrm{t}))^{2}$ で割ることで与えられる電流密度を持った電流 がメッシュの上面から流入するとして式 (1)に対応する式を導出す る. なお, $\mathrm{d}(\mathrm{t})$ は時刻 $\mathrm{t}$ におるアーク柱直径である.また, 工作 物の底面をアースと考え，底面に相当するメッシュの電位を0Vと し, 放電点と底面以外での電流の出入りはないものとした.

以上のようにして，すべてのメッシュの電位に関する方程式を
洋出し，これらの連立一次方程式を解くことによって各メッシュ の電位を計算することができる，また，後述するようにアータ柱 直径 $d(t)$ は時間とともに変化するので, 各時刻にごとに電位分布を 計算する．ただし，表皮効果は考虑しなかった。

\section{3 ジュール発热分布解析}

前節に示した電位分布解析の結果から各メッシュで生じる ジュール発熱を計算する方法を以下に述べる.メッシュ $(\mathrm{m}, \mathrm{n}) に お$ ける軸方向下向き及び半径方向外向きの電流密度 $j_{2}, j_{1}$ は, 上下及 び内外に接するメッシュの電位より各々次のように書ける.

$$
\left\{\begin{array}{l}
j_{Z}=\frac{v_{m, n-1}-v_{m, n+1}}{2 \rho \Delta Z} \\
j_{r}=\frac{v_{m-1, n}-v_{m+1, n}}{2 \rho \Delta r}
\end{array}\right.
$$

また, $\mathrm{j}_{\mathrm{r}}$ と $\mathrm{j}_{\mathrm{Z}}$ の合成べクトルの大きさ|J|は次のようになる

$$
|J|=\sqrt{j_{r}^{2}+j_{Z}^{2}}
$$

したがって, 各メッシュで生じる単位時間当たりのジュール発 然 $\mathrm{P}_{\mathrm{m}, \mathrm{n}}$ は, Vをメッシュの体積として次のように書ける.

$$
P_{m, n}=\rho V_{m, n}|J|^{2}=\rho V_{m, n}\left[\left(\frac{v_{m, n-1}-v_{m, n+1}}{2 \rho \Delta Z}\right)^{2}+\left(\frac{v_{m-1, n}-v_{m+1, n}}{2 \rho \Delta r}\right)^{2}\right]
$$

\section{4 温度分布解析}

あるメッシュ $(m, n)$ に着目したとき，ある時刻 $t^{p}(=p \times \Delta t$. $\mathrm{p}=0,1,2 \cdots, \Delta$ (は時間ステップ)において, 上下及び内外に隣接す るメッシュから流入する単位時間当たりの熱量Q中は, 図3において 電流を熱流に置き換えて考えると次のように表される.

$$
Q^{p}=Q^{p_{1}}+Q^{p_{2}}+Q^{p_{3}}+Q^{p_{4}}
$$

また, メッシュ $(\mathrm{m}, \mathrm{n})$ で生じる単位時間当たりのジュール発舤は $\mathrm{P}_{\mathrm{n}, \mathrm{n}}$ である.よって, このメッシュの時刻 $\mathrm{t}^{\mathrm{p}}$ から $\mathrm{t}^{\mathrm{p}+1}(=(\mathrm{p}+1) \times$ $\Delta \mathrm{t})$ の間の温度上界は次式で与えられる。

$$
\rho_{d} c V_{m, n} \frac{T_{m, n}^{p+1}-T_{m, n}^{p}}{\Delta t}=Q^{p}+P_{m, n}
$$

ただし， $\rho_{d}, c は$ cはぞれ L作物の密度，比熱である．

以上からメッシュ $(\mathrm{m}, \mathrm{n})$ の温度に関する方程式が以下のように得 られる。

$$
\begin{aligned}
T_{m, n}^{p+1}= & \frac{\lambda \Delta t}{\rho_{d} c V_{m, n}}\left(\frac{T_{m, n-1}^{p}-T_{m, n}^{p}}{Z} S_{1}+\frac{T_{m, n+1}^{p}-T_{m, n}^{p}}{\Delta Z} S_{2}+\right. \\
& \left.\frac{T_{m-1, n}^{p}-T_{m, n}^{p}}{\Delta r} S_{3}+\frac{T_{m+1, n}^{p}-T_{m, n}^{p}}{\Delta r} S_{4}\right)-T_{m, n}^{p}+\frac{\Delta t}{\rho_{d} c V_{m, n}} P_{m, n}
\end{aligned}
$$

ここで，入は熱伀導率，Tは各メッシュの絶対温度である.

したがって，時刻 ${ }^{\mathrm{p}}$ におけるメッシュ $(\mathrm{m}, \mathrm{n})$ に隣接するメッシュ の温度が分かれば，それらを用いて $\Delta \mathrm{t}$ 秒後のメッシュ $(\mathrm{m}, \mathrm{n})$ の沮 度を求めることができる.

ここで，極間に投入される全放電パワー $\mathrm{P}_{\mathrm{g}}$ のうち，沓作物へ流 入する割合を $\alpha$ とする. このパワー $\alpha \mathrm{P}_{\mathrm{g}}$ がアーク柱から亡作物へ 一様な分布を持って流人すると仮定した。したがって，アーク柱 から熱流入のあるメッシュにおいては，I:作物へ流入するパワー $\alpha \mathrm{P}_{\mathrm{g}}$ をアーク柱の断面棈で割ることで与えられる就流束がメッ シュの上面から流入するとして式 (7)に対底する式を導出する. な お, 放電点以外の工作物表面にはすべて断熱条件を適用し，初期 条件として工作物は時刻0においてすべて室温 $(=300 \mathrm{~K})$ であるとした.

2.5 アーク柱值徍の時間変化

4. 1節で後述する方法により求めたアーク柱直径の時間変化を考 感に入れて一連の計算を繰り这し行う。つまり，時間経過ととも に, 電流及び熱流束の流入する川板状の領域の直径 $\mathrm{d}(\mathrm{t})$ を変化さ せて，1问の放電が終了する時刻まで電位分布解析及び熱伝草解 析を綝り这す。 


\begin{tabular}{|c|c|c|}
\hline & $\begin{array}{c}\text { ceramics } \\
\left(\mathrm{Si}_{3} \mathrm{~N}_{4}-\mathrm{SiC}\right)\end{array}$ & $\begin{array}{c}\text { steel } \\
\text { (tool steel) }\end{array}$ \\
\hline $\begin{array}{l}\text { Thermal conductivity } \lambda \mathrm{W} /(\mathrm{mK}) \\
\text { Density } \rho_{\mathrm{d}} \mathrm{kg}^{3} \mathrm{~m}^{3} \\
\text { Specitic heat c } 1 /(\mathrm{kgK}) \\
\text { Melting point } \mathrm{I}_{\mathrm{m}} \mathrm{K} \\
\text { Specific resistance } \rho 2 \mathrm{~cm}\end{array}$ & $\begin{array}{c}46.7 \\
3.30 \times 10^{3} \\
7.45 \times 10^{2} \\
2200 \\
3.0 \times 10^{-1} \\
\end{array}$ & $\begin{array}{c}45.1 \\
7.83 \times 10^{3} \\
4.61 \times 10^{2} \\
1800 \\
1.5 \times 10^{-5} \\
\end{array}$ \\
\hline
\end{tabular}

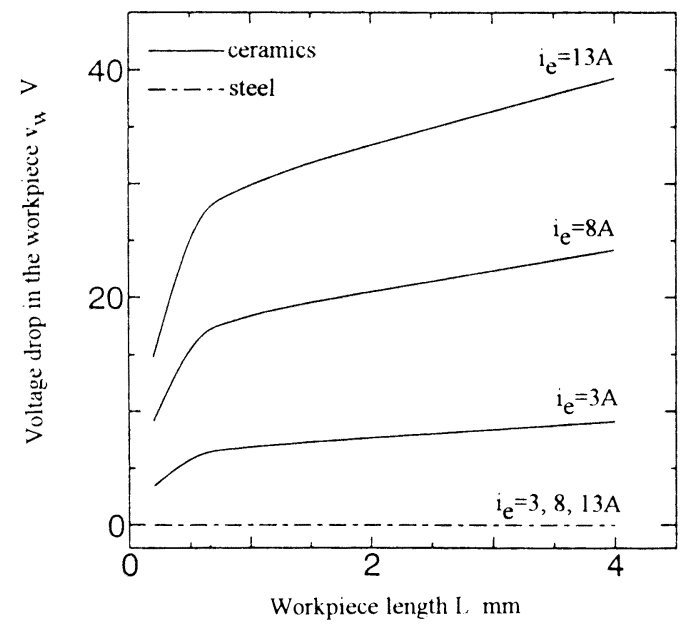

Fig.t Relationship between workplece length and the voltage drop $v_{w}$ as a function of discharge current

\section{3. 整位分布解析結果}

\section{1 笛位分布解析絬果}

本研究に用いた高抵抗材料は，衣にに衣す組成の窣化けい素系セ ラミックスである. また，これと比較するための良導電材料とし て炭素についても解析及び奏験を行つた，表にに今们用いたセラ ミックス及び苂絭の物性值をホすす。なお，解析においては両材 料とも久陷及び異方性のない均質な材料と仮定した.

電位分布解析では，I:作物の小法は奏験に用いたI作物を考虑 して，I作物の直径 $\mathrm{D}=4 \mathrm{~mm}$ とし，放電電流 $\mathrm{i}_{\mathrm{e}}$ とエ作物の長さしを 各々変化させて計算を行つた。

セラミックス及び炭素について，放電電流 $\mathrm{i}_{\mathrm{e}}$ をパラメータと してI:作物拉さLとI:作物内の電た: 降ト $\mathrm{V}_{\mathrm{W}}$ の関係の計算結果を図4

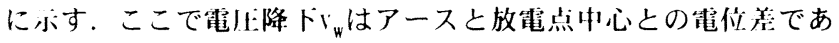

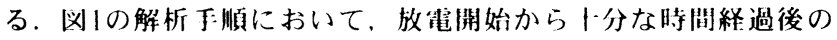
アーク柱值径がほぼ定常做に这した状態を考虑してアーク柱值径

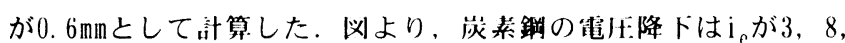
13Aのすべての場合でほぼ0Vである. それと比較してセラミックス 内の電厌降下は非常に人きいことがわかる. また, 㫣厌降下は放 電電流 $\mathrm{i}_{\mathrm{e}}$ に比例し, 「作物店さしが約 $1 \mathrm{~mm}$ 以上ではLに比例して增加 することがわかる．次にセラミックス内の電位分布解析結果の一例として $\mathrm{i}_{\mathrm{e}}=13 \mathrm{~A}, \mathrm{~L}=4 \mathrm{~mm}$ の塨命の $\mathrm{I}$ 作物内の等電位面及び電流の流 線を図5に示す。网より，セラミックス内で生じる電忙降下の大部 分は, 電流密度の大きな放電点近傍で牛じており， $Z=1 \mathrm{~mm}$ 以上の部 分では電流が、作物断面上でほぼ椂に流れていることがわかる.

\subsection{L作物内部での重压降トの测定}

I:作物内の電生降ト $v_{w}$ を古接測定することは困難である。しか

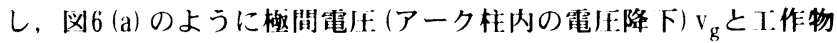
及び $\mathrm{I}$ 具電極内部での電龙降ド $v_{w}, v_{e}$ の和として定義する放電中の 放電電厓の測定は容易である.

銅電梪を用いてセラミックスと岑少銅をそれぞれ放電電流

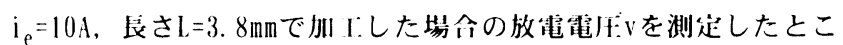

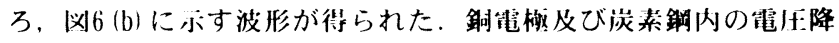

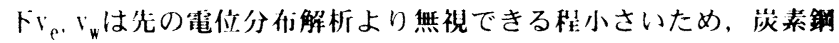

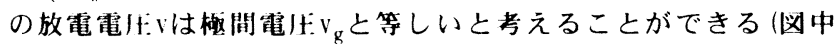

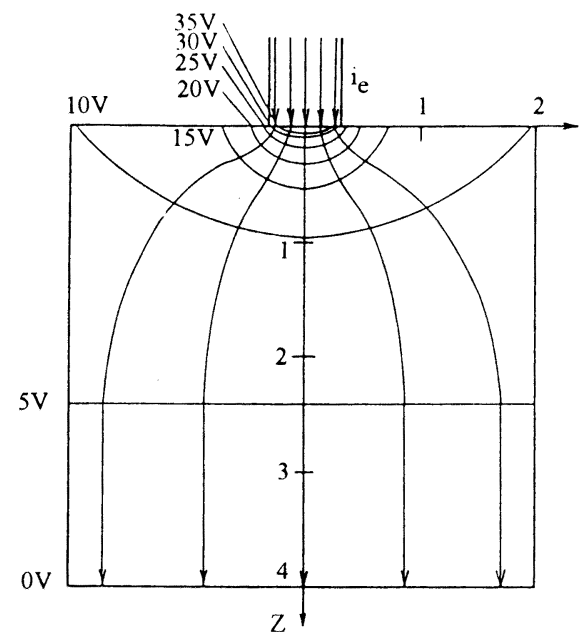

Fig.5 Equipotential surface and streamline of current in the workpiece $\left(\mathrm{L}=4 \mathrm{~mm}, \mathrm{i}_{\mathrm{e}}=13 \mathrm{~A}\right)$

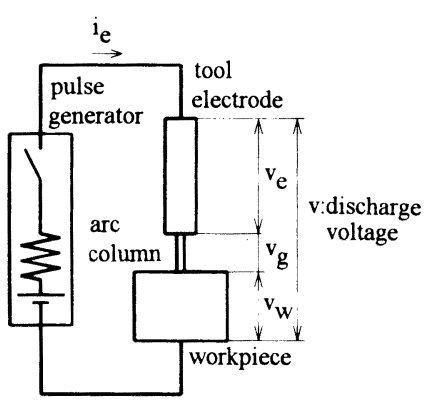

(a) Equivalent circuit

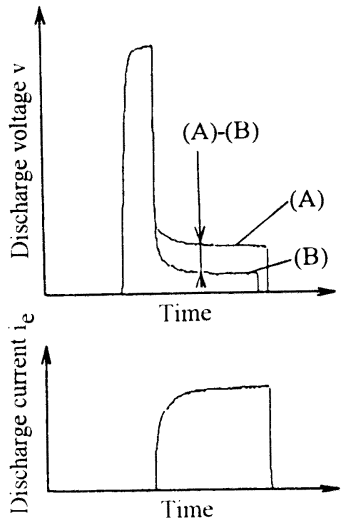

(b) Discharge pulse waveform
Fig.6 Method of measurement of the voltage drop in ceramics workpiece

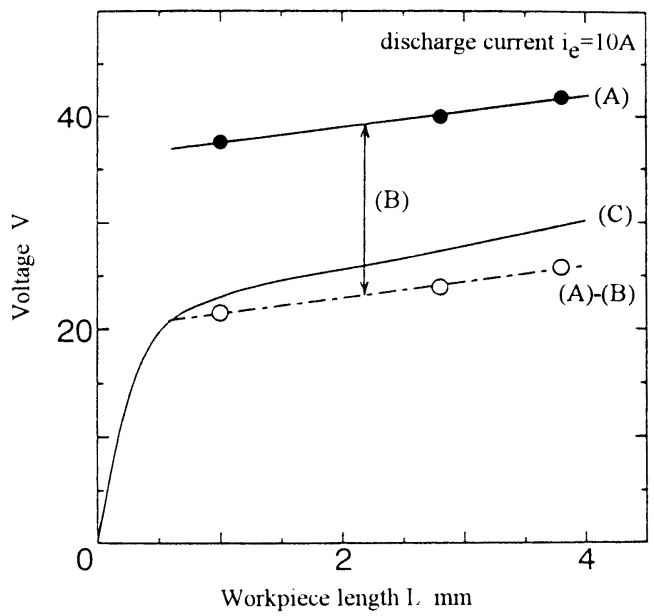

Fig.7 Comparison between the calculated and the measured voltage drop in ceramics

(B))。 セラミックスと炭素骼でアーク柱の性質が等しく，した がって極間電压 $v_{\mathrm{g}}$ が等しいと仮定すれば，セラミックス内の電圧 降下 $\mathrm{v}_{\mathrm{w}}$ は, セラミックスを加工したときの放電電压（図中 (A))か ら $\mathrm{v}_{\mathrm{g}}$ を差し引いて求められる（涵中 $(\mathrm{A})$ - (B)) .

図7に，上記の方法で実験により求めたセラミックス内の電圧降 下 (図中 (A) - (B) ) と2. 2節の方法で解析により求めたセラミックス 内の電压降下(図中(C))の工作物長さによる変化を示す。四より， 「作物长さしがリ血以上で尖験から求まった電庄降下 $(\mathrm{A})$ - (B) 及び計 算で求まった電圧降下(し)はほぼ直線で, しかも值が近いことから、 


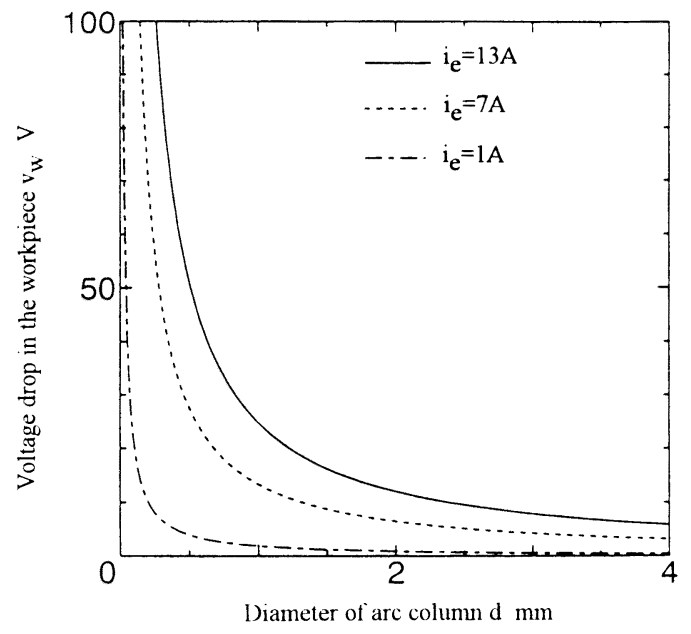

Fig.8 Relationship between diameter of arc column and voltage drop as a function of discharge current

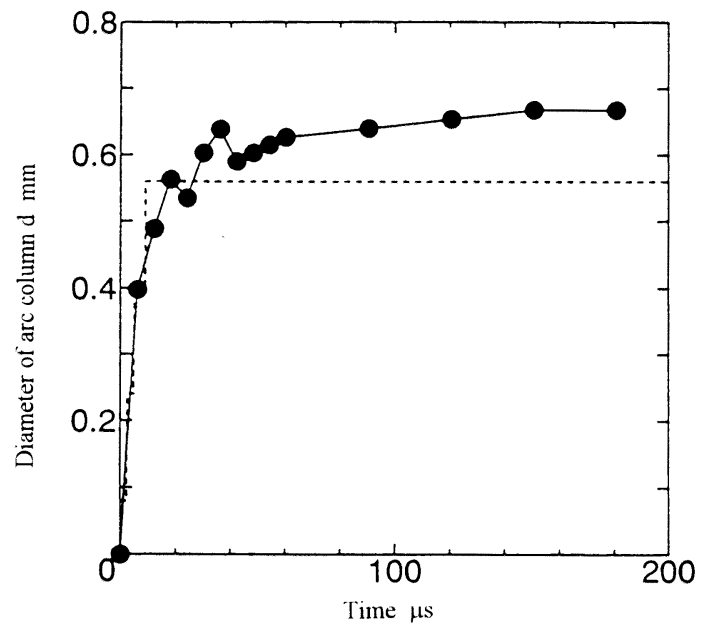

Fig.9 Expansion of arc column

$Z=1 \mathrm{~mm}$ 以上で工作物断面内の電流密度がほほ一様であるという結果 および電压降下の結果は, それぞれ定性的, 定量的に妥当である と考えられる.

\section{4. アーク柱の膨張の测定}

4. 1 アーク柱の膨張の测定方法

アーク柱直径は，その測定が困難なことから放電により形成さ れた放電痕直径より類推することが一般的である11112)。しかし， より正確にアーク柱直径の時間変化を求めるために, 以下に示す 方法を本研究で新たに考案した. まず，アーク柱直径と放電電流 をそれぞれ変化させて電位分布解析を行い，セラミックス内の電 圧降下をアーク柱直径と放電電流の関数として求める. 次に実際 に加工を行い, 1回の放電パルス内において, 絶縁破壊直後から時 間とともに変化するセラミックス内の電圧降下と放電電流を計測 する. そして, これらの值を先に求めた関数に代入してアーク柱 直径について解く. 以上の手順を放電持続時間中の各時刻につい て行うことによってアーク柱直径の時間変化が求まる.

\section{2 アーク柱の膨張の测定結果}

図8に放電電流をパラメータとしてアーク柱直径とセラミックス 内電圧降下の関係の解析結果を示す，図より，各々のアーク柱直 径における電圧降下は放電電流に比例して大きくなることが分か る.この結果からセラミックス内の電圧降下を放電電流とアーク 柱直径の関数として表すと次式のようになる.

$$
V_{w}=i_{e} \times\left(-0.00747+\frac{0.00158}{d^{3}}+\frac{0.01554}{d^{2}}+\frac{1.87024}{d}\right)
$$

Table2 Machining conditions used in the calculation

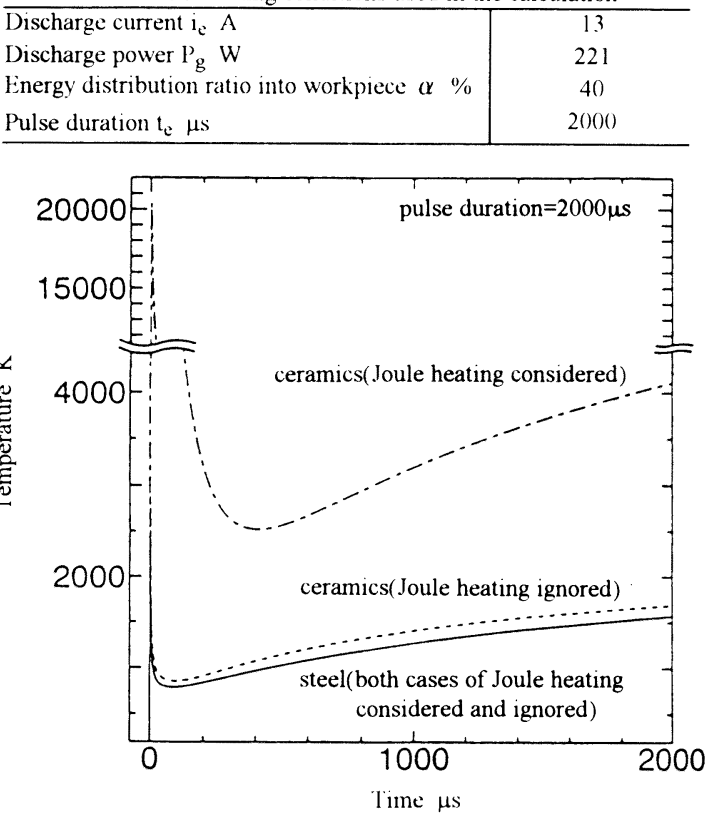

Fig. 10 Temperature change at the center of discharge spot

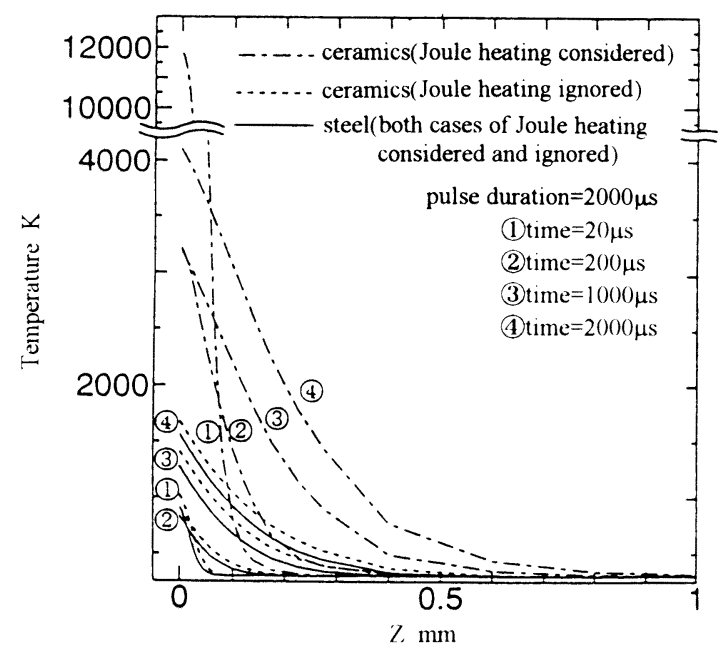

Fig.11 Variation of temperature distribution along the axis of workpiece

ここで，3.2節のカ法でセラミックス内の電长降トを実験より求 め, さらにこの時の放電電流を姑測し、式(8) を用いてアーク柱の 膨張を求めた結果を四 9 に亦す。困よりアーク柱は放電開始直後に 急激に膨张し，それ以後は緩やかに膨绂することがわかる．また， 放電終盤のアーク柱直径は, 间梯の条件での嵒発放電により形成

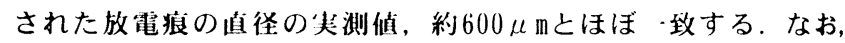
図 1 の解析に用いるときには部算の便目をはかるために, 困中の 破線に示すような段階的なアーク柱面径の時間変化を仪定して計 算した.

\section{5. ジュール発热を考虚した沮度分布解析結果 と加厂現象との関連}

\section{1 温度分布解析結果}

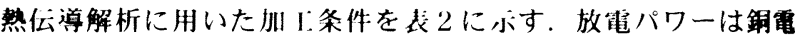

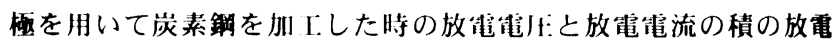

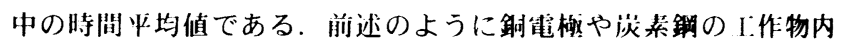
での䉓压降下は無視できる程小さいため,これはアーク柱のみで 生じるパワーと考えられる。夏ら尚の尖測值を参考にして，この

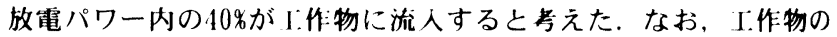




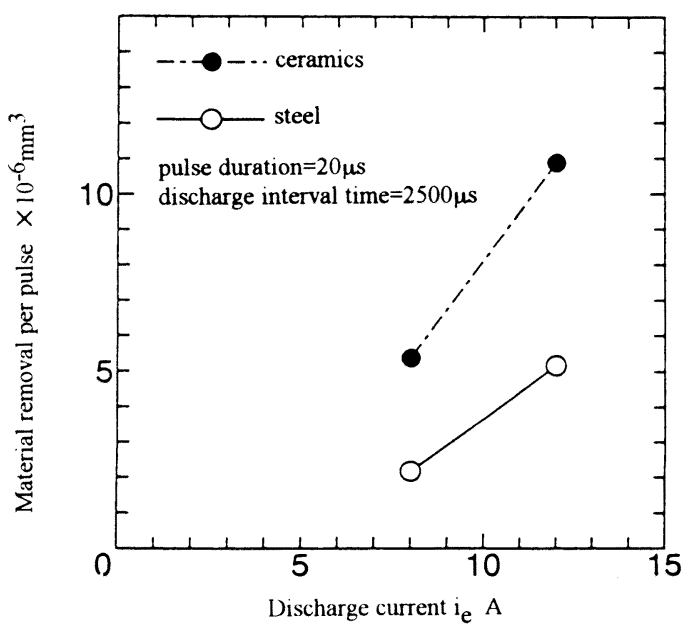

Fig.12 Experimental result of material removal per pulse

長さしが2mmの場合について計算を行つた.

表1，2に示す条件と図9に示すアーク柱值径を用いて，セラミッ クス及び炭素䤡について各々ジュール発熱を考虑した場合と無視 した場合について熱伝導解析を行った. 図10に放電点中心 $(\mathrm{r}=\mathrm{Z}=0)$ の温度の時間変化を, 図11にI:作物中心軸 $(Z$ 軸) 上の温度分布の 時間変化をそれぞれ示す．眓10より炭素䤡の場合はジュール発熱 の考虑の有無によらずほぼ同じ温度変化を示すのに対して，七ラ ミックスの場合はジュール発熟の考虑の有無によって温度が大き く異なっていることが分かる. 特に放電開始直後のアーク柱が細 い時点での違いが顥著である. また, 図11よりジュール発熱があ る場合，時間経過とともにかなり深い領域まで高温になることが 分かる.これらの結果より, セラミックスの加工の場合, アーク 柱からの熱流入に加えてジュール発熱もかなりの割合で除去機構 に関与していることが分かる.

\section{2 実験による放電 1 回当たりの除去体積}

解析と同じ条件において実際に加亡を行い, 放電 1 回当たりの 除去体積を実験により求めた結果を図 12 に示す。放電 1 回当たり の除去体積は，ある時間加 I：した場令の除去体積を加 I時間中の 全放電パルス数で割ることによって求めた。 なお，加工条件は放 電持続時間 $20 \mu \mathrm{s}$, 放電休止時間 $2500 \mu \mathrm{s}$ である. 図より, 炭素銅 よりも融点の高いセラミックスの方が放電 1 回当たりの除去体積 が大きいことが分かる.もっとも, 導電性のあるセラミックスの 除去メカニズムが金属のような溶融除去的ではなく破砕除去的と いう報告もある ${ }^{3 / 4)}$ 。その場合は溶融にエネルギーが消費されるこ となく固相のまま除去されるため、除去が浴融蒸発のみによる場 合に比べ加工速度が增大すると推測されている，しかし，本研究 の結果より, ジュール発熱によって溶融領域が拡大される効果も 無視できないと思われる. また, 温度上昇により破砕が促進され る効果も考えられる.

\section{3 考察}

実駼より裏付けられるように, 放電 1 回当たりの除去体積はむ しろ炭素よりセラミックスの方が大きい. それにもかかわらず 実際のセラミックスの加 $\mathrm{I}$ 速度が炭素制に比べて非常に小さい理 由として次のように考える. つまり, 高抵抗材料の場合, ジュー ル発熱により I作物の深い領域まで高温になるため, 放電休止時 間中のプラズマの消沈に長い時間を要する14) 15)。そのため放電休 止時間を炭素龢の場合に比べて極端に長くとり放電頻度を極端に 小さくして加亡を行う必要がある. その結果, 加工速度は炭素策 に比べて小さくならざるを得ないものと考えられる.

一方，今回のセラミックスは炭素成とほほ同じ就伝導率であり， ジュール発熱を考虑しない熱伝導解析では炭素鎆の場合とほほ同 じ湿度上昇である。つまり, 今回用いたセラミックスが良導電体 であると仮定すれば，炭素鎆とほほ同じ温度上昇しか晛れない．
しかし，一般のセラミックスの热伝導本は，炭素鹤などに比べて 小さい場合が多い。したがって，たとえ良導電体であっても，慗 が放電点付近に停留しアークになりやすい2). しかも本研究で明ら かにしたように, 高抵抗材料であるためジュール発熱によってさ らに放電点近傍の温度が上昇するために非常にアークになりやす くなっているものと考えられる.したがって, 導電性セラミック スなどの高抵抗材料の放電加工において, 加工速度の向上のため の指針としては, 極間への加工液の強制噴流などの方法によって 放電点の冷却を積極的に行い，プラズマの消沈を促すことで放電 休止時間を短くすることが有効であることが分かる. それが可能 ならば炭素鋼に匹敵する加工速度が実現できると考えられる.

\section{6. 結 言}

本研究では新たな方法でアーク柱の膨張を求めた上で, 工作物 内の電気抵抗に起因するジュール発熱を電位分布解析結果より計 算した. そして, 熱源としてその他にアーク柱からの熱流入も考 虑して一つの放電パルスにおける工作物温度の数值解析を行った. その結果, 高抵抗材料の放電加工について次のことがわかった.

・放電中に高抵抗材料内部で無視できないほど大きな電圧降下が 生じ, このうちの大部分は放電点近傍で生じている.

- 高抵抗材料の電圧降下の解析結果と実験結果を比較することに より, 絶縁破俵直後からのアーク柱の膨張の様子が解明された. ・アーク柱からの熱流束に加えて工作物内のジュール発熱もかな りの割合で工作物の温度上昇に関与している.

・本研究に用いたセラミックスの方が放電 1 回当たりの除去体積 が大きくなった原因の一つとして，ジュール発熱によって溶融 領域が拗大される効果が無視できないと思われる.

・ジュール発熱により放電点近傍の工作物の温度が上昇するため, 放電の安定には放電休止時間を炭素鋼などに比べて極端に長く して加工を行う必要があり, 加工速度は炭素鎆に比べて小さく ならざるを得ないものと考えられる.

- 加工速度向上の指針として, 極間への加工液の強制噴流などの 方法で放電点の冷却を積極的に行い, プラズマの消沈を促すこ とで放電休止時間を短くすることが挙げられる.

\section{参考文 献}

1) 中村 守, 久保勝司, 平井幸男 : 反応焼結炭化珪素の放電加工, 気加工技術, 8,22(1984) 1 .

2) 斎藤長男: ファインセラミックスの放電加工, 機械と工具, 33,5 (1989) 121 .

3) W.König, D.F.Dauw, G.Levy and U.Panten : EDM-Future Steps towards the Machining of Ceramics, Ann.CIRP, 37, 2 (1988) 625.

4）万波和男，酒井恒蔵，奥宮正太郎： $\mathrm{ZrB}_{2}$ 系セラミックスの放電加工, 電気加工技術, 10, 27 (1986) 7

5) G.Wollenberg, M.Timm, T.Pape and H.P.Schulze : Stepped Pulse Power Supply and Feedrate Control for EDM of Materials Which Are Poor Conductors, ISEM-11 (1995) 353.

6) Y.Jizhen : Some Research on the EDM of Non Electric Conductive Material, ISEM-10 (1992) 223.

7) Y.F.Luo, C.G.Chen and Z.F.Tong : Slicing Thin Silicon Wafers by Wire EDM Cutting, ISEM-10 (1992) 287

8) C.Fengguo : A New Technology of High-speed Machining Polycrystalline Diamond with Increased Discharge Breakdown Explosion Force, ISEM-9 (1989) 309 .

9) J.A.Rich : Resistance Heating in the Arc Cathode Spot Zone, J.Appl.Phys., 32, 6 (1961) 1023

10) 風 誠三郎：放電加工のメカニズム, 精密機械, 29, 10 (1963) 11 .

11) A.S.Zingerman : The Effect of Thermal Conductivity upon the Electrical Erosion of Metals, Soviet Phys.-Tech. Phys.,(1956) 1945.

12）向山芳世, 楊友沈: 放電加工における溶融首の 3 次元解析, 電気加 工学会誌, 26, 53 (1992) 13.

13）夏 恒, 国枝正典, 西脇信彦: 放電加工における実加工中のエネル キ配分の測定, 1994年度精密工学会秋季大会学術講演会講演論文集 (1994) 269.

14) 元木幹雄, 小野雅幸, 上出諭吉 : 放電加工のギャップ現象, 電気加 工学会誌, 8, 15 (1975) 44

15）室岡義広, K.R.Hearne：絶縁破墙電圧に及ほす電極温度の影䇺, 電 気学会詥文誌A, 92, 9 (1972) 19 . 